Wilfrid Laurier University

Scholars Commons @ Laurier

1976

\title{
Isolation of Peroxidase Isozymes from Two Flax Genotypes by Column Chromatography
}

Mary Ann Fieldes

Wilfrid Laurier University, mfieldes@wlu.ca

N. Bashour

McGill University

C.L. Deal

McGill University

H. Tyson

McGill University

Follow this and additional works at: https://scholars.wlu.ca/biol_faculty

\section{Recommended Citation}

Fieldes, Mary Ann; Bashour, N.; Deal, C.L.; and Tyson, H., "Isolation of Peroxidase Isozymes from Two Flax Genotypes by Column Chromatography" (1976). Biology Faculty Publications. 17.

https://scholars.wlu.ca/biol_faculty/17

This Article is brought to you for free and open access by the Biology at Scholars Commons @ Laurier. It has been accepted for inclusion in Biology Faculty Publications by an authorized administrator of Scholars Commons @ Laurier. For more information, please contact scholarscommons@wlu.ca. 


\title{
Isolation of peroxidase isozymes from two flax genotypes by column chromatography
}

\author{
M. A. Fieldes, N. Bashour, C. L. Deal, and H. Tyson \\ Department of Biology, Mc Gill University, Montreal, Quebec \\ Received September 9. 1975
}

Fieldes, M. A., N. Bashour, C. L. Deal, and H. Tyson. 1976. Isolation of peroxidase isozymes from two flax genotypes by column chromatography. Can. J. Bot. 54: 1180-1188.

Isolation of the four major peroxidase isozymes (isozymes 1.2.3. and 4) of two flax genotypes was achieved by modifying the procedure used by Shannon et al. (1966) for the isolation of horseradish peroxidase isozymes. The net positive and net negative charges of isozymes 1,2, and 4 were different. Isozyme 3 resembied isozyme 4 in charge but differed in apparent molecular weight. The chromatographic elution profiles of both genotypes were the same. Anionic gel electrophoresis demonstrated that after isolation and repurification, relative mobility differences existed between the corresponding isozymes of the two genotypes for all four isozymes.

Fieldes, M. A., N. Bashour, C. L. Deal et H. Tyson. 1976. Isolation of peroxidase isozymes from two flax genotypes by column chromatography. Can. J. Bot. 54: 1180-1188.

Les auteurs ont isolé les quatre principaux isozymes de la peroxydase (isozymes 1,2,3 et 4) de deux génotypes de lin, en modifiant la technique utilisée par Shannon et al.(1966) pour isoler les isozymes de la peroxydase du raifort. Les charges positives nettes et négatives nettes des isozymes 1,2 et 4 sont différentes. L'isozyme 3 ressemble à l'isozyme 4 par sa charge mais en diffère par le poids moléculaire apparent. Les profils d'élution chromatographiques des deux génotypes sont les mêmes. L'électrophorèse anionique sur gel a démontré que, après isolement et repurification, il existe des différences de mobilité relative entre les isozymes correspondants des deux génotypes, et ce pour les quatre isozymes.

[Traduit par le journal]

\section{Introduction}

Acrylamide gel electrophoresis has been used to investigate the anionic peroxidase isozyme patterns of two flax genotypes, Royal (R) and Mandarin (M), and of the two flax genotrophs, Large (L) and Small (S), environmentally induced in a third genotype Stormont Cirrus (Fieldes and Tyson 1972, 1973a, 1973b). Overall electrophoretic patterns and isozyme relative mobilities $(R m s)$ indicated that the same four isozymes occur in each of the genotypes and in each of the genotrophs. This was further substantiated by the behaviour of the $F_{2}$ hybrids between the genotypes and the $F_{1}$ hybrids between the genotrophs. Comparative analysis of isozyme $R m$ has indicated that the $R m$ differences, and thus, by extension, differences in the molecular structure of peroxidase, in flax may occur at three levels. (a) Isozymic differences: the anionic electrophoretic patterns show four major isozymes, one fast migrating isozyme of high activity and three slower isozymes of lesser activity. (b) Genotypic differences: earlier studies suggested that two of the four isozymes of $R$ migrate slower than the corresponding isozymes of $\mathrm{M}$; current indications are that all four isozymes behave in this way (Fieldes, unpublished). (c) Genotrophic differences: the environmental induction of the heritable changes distinguishing the contrasting genotrophs, $\mathrm{L}$ and $\mathrm{S}$, has been fully described elsewhere (Durrant 1962a, 1962b, 1971). Genotrophs L and S were induced in the flax genotype Stormont Cirrus by one generation's growth in high levels of either nitrogen, phosphorus, and potassium (induction of $\mathrm{L}$ ) or nitrogen and potassium (induction of S). Successive progeny generations resulting from complete selfing in each previous generation were grown in uniform environmental conditions. In each progeny generation the progenies of the two fertilizer treatments (genotrophs $\mathrm{L}$ and $\mathrm{S}$ ) behaved phenotypically as distinct genotypes. Relative mobility analysis of $\mathrm{L}$ and $\mathrm{S}$ isozymes showed that all four isozymes of S migrate slower than the corresponding isozymes of $\mathrm{L}$. The modifications in isozyme structure which result in genotypic differences may be similar to those resulting in genotrophic differences. However, the distinction between these differences is the difference in their origins; genotypes were pro- 
duced through selection while genotrophs were produced through environmental induction.

The first step towards examining the modifications in peroxidase molecular structure which give rise to any one of the levels of $R m$ differences involves the isolation and purification of the individual peroxidase isozymes. Column chromatography has been used to separate and purify seven isozymes of horseradish peroxidase (Shannon et al. 1966). The adaptation of the method of Shannon et al. for the separation of the four peroxidase isozymes of flax genotypes $\mathrm{R}$ and $\mathrm{M}$ and the purification of three of these isozymes is reported here, together with some preliminary information on the structural differences between the four isozymes.

\section{Materials and Methods}

\section{Plant Material and Initial Extraction}

Plants of both genotypes were grown simultaneously in a random design in a controlled-environment chamber. The seedlings were grown in vermiculite supplied with constant volumes of an inorganic nutrient solution at regular intervals. The growth chamber was set to a 20 -h day length and a temperature cycle ranging from 14 to $22^{\circ} \mathrm{C}$. The plants were harvested 37 days after sowing. Two bulk plant extracts were prepared by homogenizing together the main stem tissue of all plants harvested from each genotype, in the ratio $1 \mathrm{~g}$ stem tissue to $4 \mathrm{ml} 0.1 \mathrm{M}$ phosphate $\mathrm{pH}$ 8.0. Amberlite anion-exchange resin (IRA 400) was incorporated in the homogenization mixture $(25 \%$ weight/volume, resin/buffer). The bulk extracts were frozen and stored at $-17^{\circ} \mathrm{C}$. Samples of the thawed bulk extracts were used for further purification by the method of Shannon et al. (1966), with modifications.

Each sample was strained through nylon mesh and centrifuged at $9000 \mathrm{~g}$ for $45 \mathrm{~min}$. The supernatant was treated with ammonium sulphate. After overnight precipitation and centrifugation, the $0-35 \%$ saturation precipitate was discarded and the $35-90 \%$ saturation precipitate was collected, redissolved in a minimal volume of $0.05 \mathrm{M}$ tris(hydroxymethyl)aminomethane (Tris), $\mathrm{pH} 7.0$, and dialysed against an excess of $0.005 M$ acetate, $\mathrm{pH} 4.4$. The dialysate was centrifuged and the supernatant that collected will be referred to as the starting fraction.

\section{Cationic Exchange Chromatography}

CM-Sephadex C-50 resin was swollen and preequilibrated with $0.005 M$ acetate, $\mathrm{pH} 4.4$. Resin (2.1 g) gave column dimensions of about $26 \times 190 \mathrm{~mm}$. Samples to be fractionated on C-50 columns were dialysed against $0.005 \mathrm{M}$ acetate, $\mathrm{pH} 4.4$, before application and eluted by the following series of washes and gradients: (i) $50 \mathrm{ml}$ $0.005 M$ acetate, $\mathrm{pH} 4.4$, wash; (ii) gradient $C_{1}, 50 \mathrm{ml}$ $0.005 M$ acetate, $\mathrm{pH} 4.4,50 \mathrm{ml} 0.10 \mathrm{M}$ acetate, $\mathrm{pH} 4.4$; (iii) $50 \mathrm{ml} 0.10 \mathrm{M}$ acetate, $\mathrm{pH} 4.4$, wash; (iv) gradient $\mathrm{C}_{2}, 50 \mathrm{ml} 0.10 \mathrm{M}$ acetate, $\mathrm{pH} 4.4,50 \mathrm{ml} 0.25 \mathrm{M}$ acetate, pH 4.9; (v) $50 \mathrm{ml} 0.25 M$ acetate, $\mathrm{pH} 4.9$, wash; (vi) gradient $\mathrm{C}_{3}, 50 \mathrm{ml} 0.25 \mathrm{M}$ acetate, pH $4.9,50 \mathrm{ml} 0.50 \mathrm{M}$ acetate, $\mathrm{pH} 5.4$; (vii) $50 \mathrm{ml} 0.50 \mathrm{M}$ acetate, pH 5.4, wash; (viii) $50 \mathrm{ml} 1.0 \mathrm{M}$ acetate, $\mathrm{pH} 5.4$, wash; (ix) $50 \mathrm{ml} 2.0 \mathrm{M}$ acetate, $\mathrm{pH} 5.4$, wash. Flow rate was about $22.6 \mathrm{ml} / \mathrm{cm}^{2} \mathrm{~h}$, fraction volume was about $6 \mathrm{ml}$, and all columns were run at $5-10^{\circ} \mathrm{C}$.

Anionic Exchange Chromatography

DEAE-Sephadex A-50 resin was swollen and preequilibrated with $0.005 \mathrm{M}$ Tris, $\mathrm{pH} 8.4$. Resin $(2.0 \mathrm{~g})$ gave column dimensions of about $26 \times 200 \mathrm{~mm}$. Samples to be fractionated on A-50 columns were dialysed against $0.005 M$ Tris, $\mathrm{pH} 8.4$, before application and eluted by the following series of washes and gradients: $(i) 100 \mathrm{ml}$ $0.005 M$ Tris, $\mathrm{pH} 8.4$, wash; (ii) gradient $\mathrm{A}_{1}, 50 \mathrm{ml} 0.005$ $M$ Tris, pH $8.4,50 \mathrm{ml} 0.005 M$ Tris, $0.05 M \mathrm{NaCl}, \mathrm{pH}$ 8.4; (iii) $50 \mathrm{ml} 0.005 M$ Tris, $0.05 M \mathrm{NaCl}$, pH 8.4 wash; (iv) gradient $\mathrm{A}_{2}, 100 \mathrm{ml} 0.005 M$ Tris, $0.05 M \mathrm{NaCl}, \mathrm{pH}$ $8.4,100 \mathrm{ml} 0.005 M$ Tris, $0.50 M \mathrm{NaCl}, \mathrm{pH} 8.4$; $(v)$ gradient $\mathrm{A}_{3}, 50 \mathrm{ml} 0.005 M$ Tris, $0.50 M \mathrm{NaCl}, \mathrm{pH} 8.4,50$ ml $0.005 M$ Tris, $1.00 M \mathrm{NaCl}$, pH $8.4 ;$ (vi) $50 \mathrm{ml} 0.005$ $M$ Tris, $1.00 M \mathrm{NaCl}$, pH 8.4 wash; (vii) $50 \mathrm{ml} 0.005 M$ Tris, $2.00 \mathrm{M} \mathrm{NaCl}$, pH 8.4 wash. Flow rate was about $22.6 \mathrm{ml} / \mathrm{cm}^{2} \mathrm{~h}$, fraction volume was about $6 \mathrm{ml}$, and all columns were run at $5-10^{\circ} \mathrm{C}$.

\section{Gel Filtration Chromatography}

Sephadex G-100 resin was swollen and preequilibrated with $0.005 M$ Tris, $\mathrm{pH}$ 8.4. Resin ( $23 \mathrm{~g}$ ) gave column dimensions of about $16 \times 1700 \mathrm{~mm}$. Samples to be fractionated were concentrated to $2.0 \mathrm{ml}$ and dialysed against $0.005 M$ Tris, $\mathrm{pH} 8.4$, before application. The elution buffer was $0.005 M$ Tris, pH 8.4 , flow rate was about 3.8 $\mathrm{ml} / \mathrm{cm}^{2} \mathrm{~h}$, fraction volume was about $1 \mathrm{ml}$, and the column was run at room temperature.

\section{Sample Concentration}

Dilute samples were concentrated on Amicon ultrafiltration equipment using UM2 membranes (nominal cutoff molecular weight, 1000) and $\mathrm{lb} / \mathrm{in}^{2}=40$.

\section{Peroxidase Activity}

The guaiacol - hydrogen peroxide technique developed by Maehly and Chance (1954) was used to assay for peroxidase activity. Peroxidase activity was expressed as the increase in optical density per minute per $0.01 \mathrm{ml}(\triangle O D /$ min $0.01 \mathrm{ml}$ ) for plotting elution patterns and as $\Delta \mathrm{OD}$ / min $\mathrm{ml}$ for all other assays.

\section{Total Protein Content}

Two estimates of total protein content were made, using the method of Lowry ef al. (1951) and alternatively the method of Waddell and Hill (1956). A bovine serum albumin standard curve was used for both methods, and for both, protein content was expressed as micrograms per millilitre.

\section{Carbohydrate Content}

The borosulphuric acid - tryptophan assay method developed by Badin et al. (1953) was used to estimate total carbohydrate content. A mannose standard curve was used and carbohydrate content was expressed as micrograms per millilitre mannose equivalents.

\section{Electrophoresis of Peroxidase Isozymes}

A detailed description of the technique and equipment used for the identification of individual isozymes by anionic acrylamide gel electrophoresis, $\mathrm{pH} 8.9$, has been given elsewhere (Hart et al. 1971). After reaction with the appropriate guaiacol - hydrogen peroxide system, elec- 
trophoretic gel tracks were scanned at $295 \mathrm{~nm}$ and optical density was recorded. Gel scans were used for qualitative visualization of the individual isozymes during isolation and $R m$ measurements obtained from scans were used for quantitative analysis. Where gel scans were used for analysis, the positions of the samples being compared were randomized in the electrophoretic cell and the mean $R m$ values from two to four gel tracks of each sample were used. The four major isozymes were numbered 1-4 in order of increasing $R m$.

\section{Genotype Replication}

The results reported here refer to an 'experiment' in which duplicate $(500-\mathrm{ml})$ samples of both genotypes $\mathrm{R}$ and $M$ were taken from the strained bulk extracts. Where possible the four samples, R1, M1, R2, and M2, were treated identically and simultaneously throughout the isolation and purification procedure; otherwise R1 and M1 were treated in tandem, as were R2 and M2. Analyses assumed that variability introduced during the procedure was, as far as possible, confounded as replicate variability with the two replicates 1 and 2 . The elution patterns and separations discussed (all of which were genotype $M$ ) are representative of the behaviour of all four samples and of all other samples processed through the same procedure, whereas the data quoted refer specifically to the four samples $R 1, M 1, R 2$, and $M 2$. Throughout the extraction procedure care was taken to avoid contamination of either genotype with the other. C-50 and A-50 columns and UM2 membranes were used exclusively for one or the other genotype. The exception was the G-100 column, where this type of precaution was physically impractical.

\section{Results}

\section{Isolation of Isozymes $1,2,3$, and 4}

The starting fraction was initially applied to a C-50 column and eluted by the C-50 elution system. The peroxidase activity elution profile obtained is shown in Fig. 1. $\mathrm{C}_{1}, \mathrm{C}_{2}$, and $\mathrm{C}_{3}$ indicate the approximate fraction number at which elution of the three acetate gradients began. Four regions, $[a],[b],[c]$, and $[d]$, of peroxidase activity separated. Region $[b]$ containing isozymes 1, 2, 3, and 4 was concentrated, dialysed against $0.005 M$ Tris, $\mathrm{pH} 8.4$, applied to an $\mathrm{A}-50$ column, and eluted by the A-50 elution system. The A-50 elution profile is shown in Fig. 2A. $A_{1}, A_{2}$, and $A_{3}$ indicate the approximate fraction number at which elution of the three $\mathrm{NaCl}$ gradients began. Five regions, $[e],[f],[g],[h]$, and $[i]$, separated. Regions $[f]$ and $[g]$ corresponded to isozymes 1 and 2 respectively. Both were repurified by repassage through A-50 columns; the elution profiles for the first repurifications are shown in Fig. 2B and 2C. Region $[h]$, which contained isozymes 3 and 4 , was concentrated, dialysed against $0.005 \mathrm{M}$ Tris, $\mathrm{pH}$ 8.4 , applied to a $\mathrm{G}-100$ column, and eluted with the same buffer. Isozyme 3 eluted before isozyme

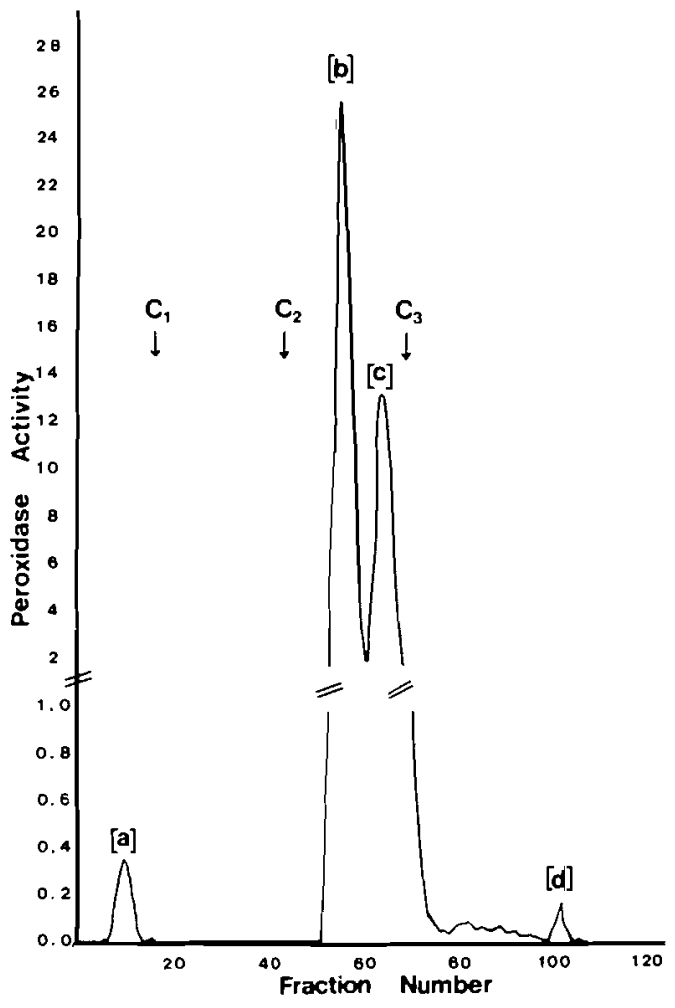

FIG. 1. C-50 peroxidase activity elution profile.

4 , forming a shoulder-like peak on the leading slope of the peak for isozyme 4 . In the peroxidase elution profile shown in Fig. 3A regions [j] and $[k]$ corresponded to isozymes 3 and 4 respectively. Isozyme 3 was repurified by repassage through the G-100 column; the elution profile for the first repurification is shown in Fig. 3B.

The peroxidase isozymes present in each elution region were checked by gel electrophoresis. The electrophoretic pattern of the four major isozymes in the bulk extract, before the isolation procedure, is shown in Fig. 4A while Fig. 4B-E shows gel scans of samples from fractions in the four isolated regions corresponding to these four isozymes.

During elution from each type of column, absorbance at $254 \mathrm{~nm}\left(A_{254}\right)$ and absorbance at $400 \mathrm{~nm}\left(A_{400}\right)$ were monitored for estimates of the protein and heme profiles, respectively. $A_{400}$ profiles corresponded to peroxidase activity profiles. $A_{254}$ profiles showed absorbance corresponding to peroxidase activity as well as additional absorbance peaks, presumed to be nonperoxidase protein. These additional absorbance 


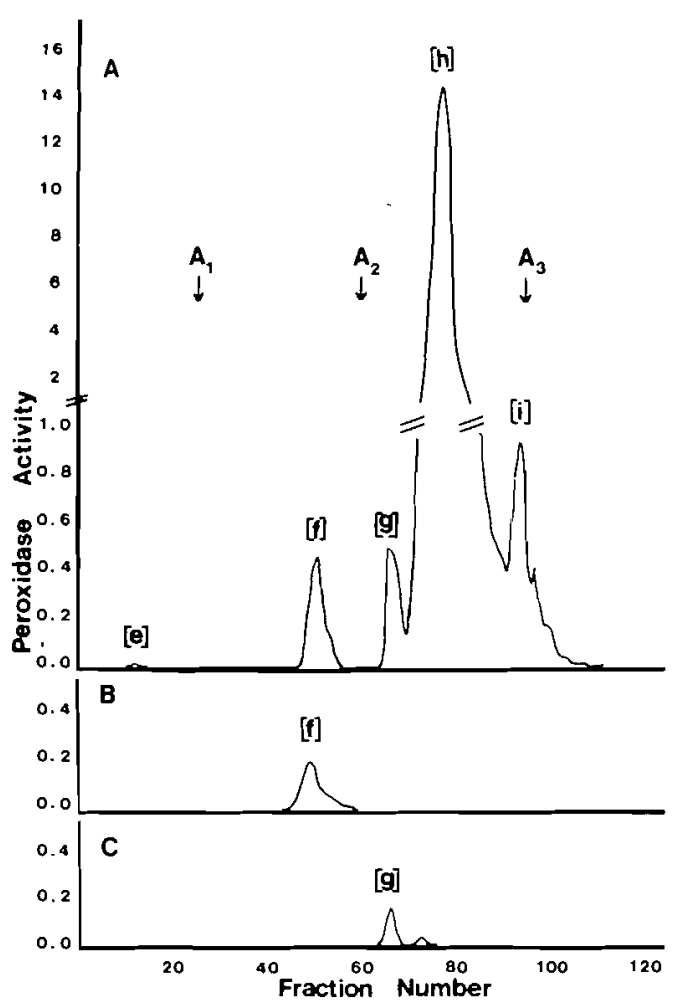

FIG. 2. A-50 peroxidase activity elution profiles.

peaks were not present in the $A_{254}$ profiles from repurification steps. The peroxidase activity profiles were more sensitive, for the presence of peroxidase, than the $A_{400}$ profiles and showed better definition, for the separation of the isozymes, than the $A_{254}$ profiles.

The peroxidase elution profiles and electrophoresis therefore indicated that after one repurification step for each isozyme, appropriate fractions of peroxidase activity could be pooled to form samples of isozymes 1,2 , and 3 which were free from other peroxidase isozymes and, according to the $A_{254}$ profiles, free from any other major source of protein contamination.

\section{Other Peroxidase Regions}

The peroxidase activity regions which separated during the isolation procedure, but were not associated with the isolation of the four major isozymes, were characterized by electrophoresis. Table 1 gives the mean $R m$ values for the electrophoretic bands of each of these regions for both genotypes averaged over replicates. It also gives the mean $R m$ s of the four major isozymes and $t$ values for comparisons made between $R m$ s from different regions.

Gel tracks to which region [d] had been applied stained intensely at the origin; the $R m$ of the peroxidase from this region thus approximated to zero. Gel scans of region $[a]$ contained trivial amounts of activity in the area of isozyme 4 and an intense band of activity in the isozyme 2 area. Relative mobility analysis, comparing this intense band with isozyme 2 , indicated that its $R m$ was significantly slower than that of isozyme 2 . Regions $[c]$ and $[i]$ appeared to pertain to isozymes 4; detailed analysis of the Rms of these regions and isozyme 4 showed that the electrophoretic band of region $[c]$ had significantly slower $R m$ than isozyme 4, whereas that of region [i] migrated with the same $R m$ as isozyme 4 . No peroxidase activity was detected in gel tracks to which samples of region $[e]$ had been applied.

\section{Genotypic Differences in $\mathrm{Rm}$}

Table 1 gives $t$ values for comparisons made between genotypes for the $R m$ s of each isozyme and for the electrophoretic bands detected in

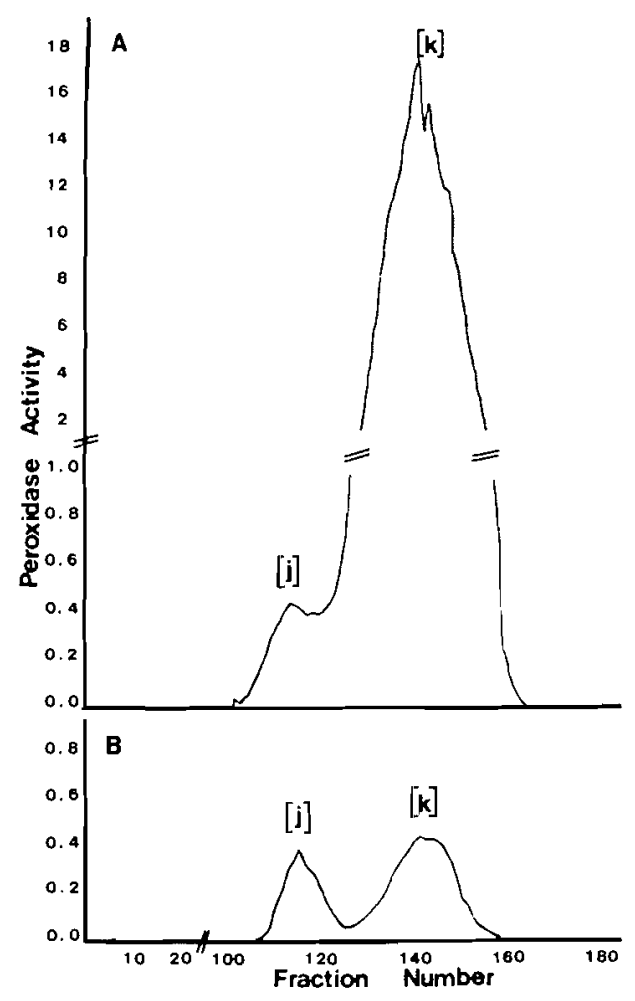

Fig. 3. G-100 peroxidase activity elution profiles. 


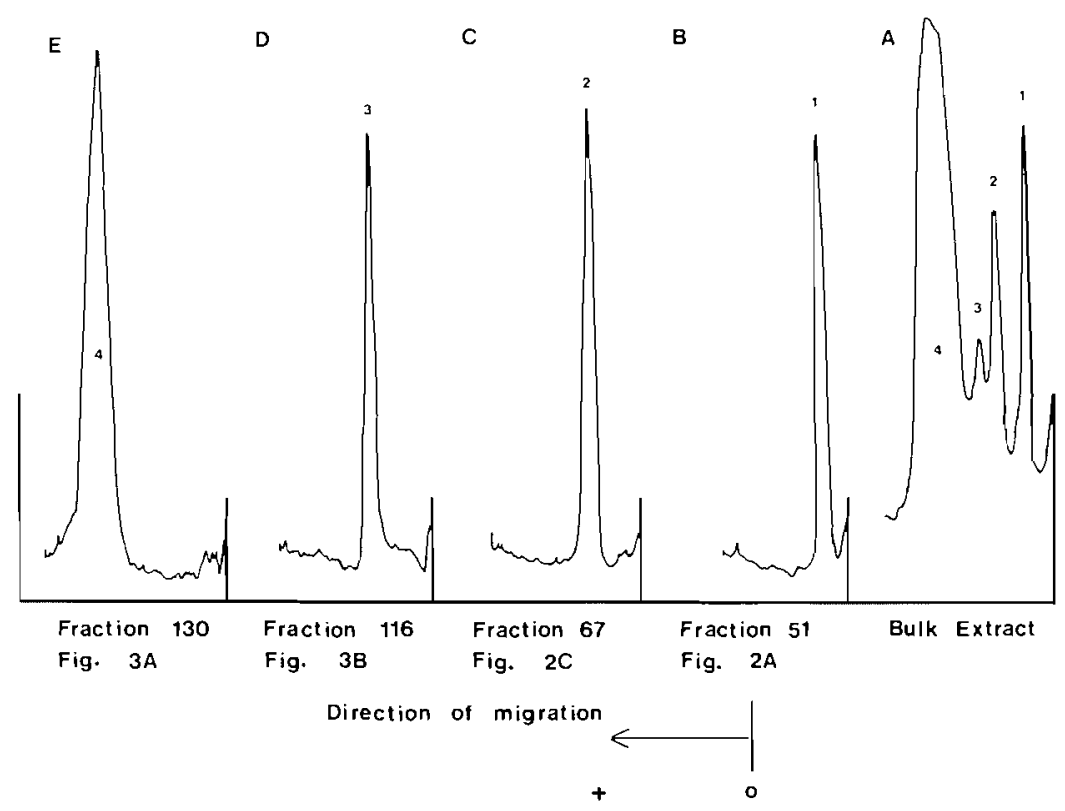

FIG. 4. Electrophoretic gel scans of the four major isozymes before and after isolation.

TABLE 1. Mean $R m$ of isozymes and electrophoretic bands from different elution regions

\begin{tabular}{|c|c|c|c|c|c|}
\hline \multirow[b]{2}{*}{ Region } & \multicolumn{2}{|c|}{ Mean $R m$} & \multirow{2}{*}{$\begin{array}{c}\text { SE } \\
\text { genotype } \\
\text { difference }\end{array}$} & \multicolumn{2}{|c|}{$t$ value } \\
\hline & $\begin{array}{c}\text { Genotype } \\
\mathrm{R}\end{array}$ & $\begin{array}{c}\text { Genotype } \\
\mathrm{M}\end{array}$ & & $\begin{array}{l}\text { Of genotype } \\
\text { difference }\end{array}$ & $\begin{array}{l}\text { Of region } \\
\text { difference }\end{array}$ \\
\hline $\begin{array}{l}{[f]} \\
\quad \text { (isozyme 1) }\end{array}$ & 0.0717 & 0.0842 & 0.002423 & $t_{3}=5.18^{*}$ & \\
\hline$[a]$ & 0.1209 & 0.1397 & 0.006890 & $t_{7}=2.73^{*}$ & $t_{7}=4.50^{* *}$ \\
\hline $\begin{array}{l}{[g]} \\
\quad \text { (isozyme 2) }\end{array}$ & 0.1379 & 0.1666 & 0.006890 & $t_{7}=4.17^{* *}$ & \\
\hline$[j]$ (isozyme 3 ) & 0.2498 & 0.2618 & 0.007894 & $t_{6}=1.52$ & \\
\hline$[c]$ & 0.3794 & 0.4344 & 0.007624 & $t_{5}=7.21^{* *}$ & $t_{5}=4.75^{* * *}$ \\
\hline $\begin{array}{l}{[k]} \\
\quad \text { (isozyme } 4)\end{array}$ & 0.4123 & 0.4527 & 0.007624 & $t_{5}=5.30^{* *}$ & $1 s=166$ \\
\hline$[i]$ & 0.4310 & 0.4518 & 0.007624 & $t_{5}=2.73^{*}$ & $15-1.00$ \\
\hline
\end{tabular}

regions $[a],[c]$, and $[i]$. In each case, $R m$ was faster in $M$ than in $R$.

\section{Percentage Recovery and Purity}

Peroxidase activity and protein content were estimated in aliquots taken at each step in the isolation procedure. All aliquots were dialysed to the same $\mathrm{pH}(0.005 M$ Tris, $\mathrm{pH} 8.4)$ and assayed after completion of the procedure. Per- centage recovery was estimated from the total number of units of peroxidase recovered (peroxidase activity per millilitre $\times$ volume, i.e. 'peroxidase yield'), and purity was estimated as the ratio of specific peroxidase activities (based on Lowry protein estimates) before and after an isolation step. Values were averaged over R1, M1, R2, and M2.

During the initial purification step, from the 
TABLE 2. Peroxidase and protein values for isozymes 1,2 , and 4 of both genotypes

\begin{tabular}{|c|c|c|c|c|c|c|c|c|}
\hline & \multirow[b]{2}{*}{$A_{400} / A_{280}$} & \multirow{2}{*}{$\begin{array}{l}\text { Per- } \\
\text { oxidase } \\
\text { yield }\end{array}$} & \multicolumn{2}{|c|}{$\begin{array}{l}\text { Protein yield, } \\
\mathrm{mg} / 500 \mathrm{ml} \text { extracl }\end{array}$} & \multicolumn{2}{|c|}{$\begin{array}{l}\text { Specific peroxidase } \\
\text { activity }\end{array}$} & \multicolumn{2}{|c|}{$\%$ carbohydrate } \\
\hline & & & Lowry & Waddell & Lowry & Waddell & Lowry & WaddeII \\
\hline \multicolumn{9}{|l|}{ Genotype $\mathrm{R}$} \\
\hline Isozyme 1 & 0.54 & 0.22 & 0.41 & 0.31 & 0.055 & 0.075 & 22.4 & 27.7 \\
\hline Isozyme 2 & 0.46 & 0.18 & 0.47 & 0.29 & 0.040 & 0.070 & 17.1 & 25.7 \\
\hline Isozyme 4 & 0.75 & 8.68 & 0.72 & 0.29 & 1.160 & 2.975 & 7.0 & 15.0 \\
\hline Mean & & 2,93 & 0.53 & 0.29 & 0.419 & 1.040 & 15.5 & 22.8 \\
\hline \multicolumn{9}{|l|}{ Genotype M } \\
\hline Isozyme 1 & 0.62 & 0.13 & 0.24 & 0.15 & 0.054 & 0.085 & 21.4 & 29.7 \\
\hline Isozyme 2 & 0.35 & 0.08 & 0.33 & 0.19 & 0.023 & 0.040 & 23.3 & 38.9 \\
\hline Isozyme 4 & 0.53 & 5.20 & 0.34 & 0.09 & 1.499 & 6.665 & 17.8 & $27.9^{a}$ \\
\hline Mean & & 1.77 & 0.30 & 0.14 & 0.525 & 2.263 & 20.8 & 32.2 \\
\hline \multicolumn{9}{|c|}{$t$ values $^{b}$} \\
\hline Genotype difference & & $2.63^{*}$ & $5.07^{* *}$ & $3.82 *$ & 2.11 & $2.75^{*}$ & 1.43 & \\
\hline $\begin{array}{l}\text { Isozyme difference, } \\
\text { isozyme } 4 \text { vs. mean } \\
1+2\end{array}$ & & $14.10^{* *}$ & $3.53^{*}$ & 1.16 & $24.05^{* *}$ & $10.08^{* *}$ & 2.19 & \\
\hline $\begin{array}{l}\text { Genotype } \times \text { isozyme } \\
\text { interaction, isozyme } 4 \\
\text { vs. mean } 1+2\end{array}$ & & $3.42 *$ & 2.38 & $<1,00$ & $3.23 *$ & $3.92 *$ & 1.04 & \\
\hline
\end{tabular}

bulk extract to the starting fraction, there was a $163 \%$ recovery, indicating the removal of peroxidase inhibitor. This purification step included the ammonium sulphate fractionation and a $\mathrm{pH}$ 4.4 fractionation (the precipitate formed when the redissolved $\left(\mathrm{NH}_{4}\right)_{2} \mathrm{SO}_{4}$ fraction was dialysed to $\mathrm{pH} 4.4$ contained minimal peroxidase activity and was discarded) and resulted in a 15.5-fold increase in purity. Recovery from the cationic column, based on the sum of the eluted peroxidase regions, averaged $88 \%$, while recovery of region $[b]$ after fractionation on the anionic column averaged $66 \%$. Fractionation of $[b]$ from the starting fraction resulted in a 3.7-fold purification. Repurification of isozyme 1 gave a six-fold purification and $87 \%$ recovery. Isozymes 2 and 3 separated from isozyme 4 during repurification. The specific activity of isolated isozyme 4 was higher than that of isozymes 2 or 3 and estimates of recovery and purity for the repurifications of isozymes 2 and 3 were therefore, as expected, artificially low.

\section{Peroxidase and Protein Contents}

Table 2 gives the comparative yields of peroxidase and protein for repurified isozymes 1 and 2 and for isozyme 4 . Protein content per millilitre in concentrated samples of isozyme 3 was low and could not be accurately estimated. Mean values, over replicates, are given for both genotypes, and the $t$ values quoted summarize the analysis of variance conducted for each characteristic. Protein yield was estimated by two different methods. When the data from both methods were compared by an analysis of covariance, the error line correlation between the two methods was positive and significant $\left(r_{4}=\right.$ +0.870 ). However, the isozyme component of the covariance analysis which compared the protein yield of isozyme 4 with the mean yield of isozymes 1 and 2 was negative. This arose from the fact that in comparing the mean protein reading for isozymes 1 and 2 with protein in 4 , the Lowry method showed isozyme 4 to be higher than the mean of 1 and 2, whereas the Waddell method yielded the opposite result. However, the Waddell difference was not significant; the Lowry difference was significant. The specific peroxidase activity of isozyme 4 was significantly higher than the mean specific activity of isozymes $L$ and 2 when either estimate of protein was used. For both methods, the protein yield from genotype $R$ was significantly higher than from $M$ and the peroxidase yield of genotype $R$ was signifi- 
cantly higher than $\mathrm{M}$; however, specific activity was higher (significantly for one method) in $M$ than in R. The significant genotype $\times$ isozyme interactions detected for activity reflected a greater difference between the mean activity of isozymes I and 2 and the activity of isozyme 4 in $\mathrm{M}$, compared with $\mathrm{R}$. No significant differences between isozymes 1 and 2 were detected.

\section{Carbohydrate Content}

The four isozymes, and other regions of peroxidase activity fractionated during the isolation procedure, gave positive reactions for the presence of carbohydrate, based on the borosulphuric acid method. Estimates of the percentage carbohydrate contents of isozymes 1, 2, and 4 for both genotypes are shown in Table 2. Based on mannose equivalents average carbohydrate content was about $23 \%$.

\section{Molecular Weight Determination}

The G-100 column used to separate isozymes 3 and 4 was calibrated for molecular weight (MW) determinations with cytochrome C, chymotrypsinogen $\mathrm{A}$, ovalbumin, and bovine serum albumin (Mann Research Labs., Ltd., New York). The elution conditions were the same as those used for the fractionation of isozymes 3 and 4 , except that $1.88-\mathrm{ml}$ samples were collected. MW estimates for isozyme 4 ranged from 42360 to 44260 . Isozyme 3 eluted ahead of isozyme 4; MW estimates for this isozyme ranged from 59000 to 64000 . Prior experimentation had suggested gel filtration as a method of fractionating isozyme 3 from the other three isozymes since elution of isozymes 1 and 2 coincided with elution of isozyme 4 and isozymes 1 and 2 are presumed to have MWs close to that of isozyme 4 .

\section{Discussion}

Isolation of the four major peroxidase isozymes of the two flax genotypes was achieved by modifying the procedure described by Shannon et al. (1966). Morita et al. (1970) have reported the isolation of peroxidase isozymes from Japanese-radish (JPR) also by using a modification of Shannon's basic procedure. The cationic and anionic elution profiles obtained for each of these three sources, horseradish, JPR, and flax, differ, although the buffers used for the isolations cover similar molarity ranges. The carbohydrate content of peroxidase from each of the sources is similar and each source contains peroxidase isozymes with $\mathrm{MW}$ in the 40000 range, although one JPR isozyme with a MW of about 30000 has been reported (Morita et al. 1971) and flax isozyme 3 has an apparent MW of about 60000 . However, in some characteristics, flax isozymes appeared to differ from horseradish and JPR isozymes. Both horseradish and JPR peroxidase isozymes exhibit heme-protein content ratios ranging from 2.5 to 4.2 (Shannon et al. 1966; Morita and Yoshida 1970) while the heme-protein content ratios (based on absorbance at $400 \mathrm{~nm} / 280 \mathrm{~nm}$ ) for flax peroxidase isozymes 1 , 2 , and 4 were less than 2.0 (Table 2). However, it seemed unlikely that this difference arose from the presence of non-peroxidase protein in the flax isozyme samples as repurification did not substantially alter the absorbance ratios; by using purified horseradish peroxidase, it was found that the $400 \mathrm{~nm} / 280 \mathrm{~nm}$ absorbance ratio was concentration dependent with concentrations of about $75 \mu \mathrm{g} / \mathrm{ml}$ and less, yielding absorbance ratios of less than 1.0. Further, at the $\mathrm{pHs}$ used, the four major (anionic) flax isozymes bound to both cationic and anionic exchange resins, indicating that their isoelectric points lie between $\mathrm{pH}$ 4.4 and 8.4. Horseradish isozymes bound to one or other of the resins (their isoelectric points therefore lie below 4.4 (for anionic isozymes) or above 8.4 (for cationic isozymes)), and similarly, anionic isozymes of JPR did not bind to cationic exchange resins at $\mathrm{pH} 4.4$.

Flax isozymes 1 and 2 were separated from each other and from isozymes 3 and 4 by anionic exchange chromatography. Examination of elution region $[b]$ indicated, however, that under appropriate conditions cationic exchange chromatography could have been used for these separations. Isozyme 2 eluted at a slightly lower acetate molarity than isozyme 1 and both 1 and 2 eluted earlier than isozymes 3 and 4 , on the leading slope of elution region $[b]$. Under both chromatographic conditions isozymes 3 and 4 eluted together. These isozymes therefore had the same net positive and net negative charges at $\mathrm{pHs} 4.4$ and 8.4 , respectively, while the net charges of isozyme 1 and 2 were lower than those of isozymes 3 and 4 at both $\mathrm{pHs}$. Isozyme 1 had a higher net positive charge and a lower net negative charge than isozyme 2 . The apparent MW difference between isozymes 3 and 4 allowed their separation by gel filtration. (Separation by gel filtration is related to both MW and molecular shape. Without further investigation, molec- 
ular shape cannot be ruled out as a possible explanation of the difference between isozymes 3 and 4.) On anionic gel electrophoresis, therefore, isozymes 1, 2, and 4 migrated with increasing $R m$ because of their increasing net negative charges, and the $R m$ of isozyme 3 was lower than that of isozyme 4 because of its higher apparent MW. For a particular protein, an estimate of the number of tyrosine and tryptophan residues per peptide bond (tyr-try/peptide) can be obtained by comparing its protein content determined by the Lowry and Waddell methods. If bovine serum albumin (BSA) were the standard for both protein determination methods, a protein with the same number of residues per peptide bond as BSA would have a tyr-try/peptide ratio of 1.0. From the protein yield data given in Table 2, the tyr-try/peptide ratios of isozymes 1,2 , and 4 are $1.3,1.6$, and 2.5 , respectively, for genotype $\mathrm{R}$ and $1.6,1.7$, and 3.8 , respectively, for genotype $M$. This increasing trend in ratio from isozymes 1 to 4 suggests that tyrosine and tryptophan may contribute to the difference in the net negative charges of the three isozymes.

During the isolation procedure, four regions of peroxidase activity were isolated aside from the four major isozymes. Priority has been given to the major isozymes and the additional regions have not been repurified or examined beyond determining their behaviour on anionic gel electrophoresis. The resemblances between the $R m s$ of regions $[c]$ and $[i]$ and isozyme 4 indicate that the electrophoretic band designated as isozyme 4 in gel scans of crude extracts was electrophoretically diverse and separable into at least two discrete components. Neither region $[c]$ nor region [i] has yet been rechromatographed. Heterogeneity, or microheterogeneity, of the carbohydrate moiety of glycoproteins can contribute to electrophoretic diversity (Montgomery 1972). This type of heterogeneity could account for diversity in any of the isozymes but may be particulary relevant in the case of isozyme 4 . All four major isozymes were stable at room temperature as well as at lower temperatures, and no interconversion among the isozymes has been detected.

The chromatographic elution profiles of the two genotypes were similar and the four major isozymes of both genotypes were isolated by identical procedures. Current investigations indicate that the isozymes of genotrophs $\mathrm{L}$ and $\mathrm{S}$ can also be isolated by the same procedure. The similarity of the elution profiles supports the contention that corresponding isozymes occur in the two genotypes and the two genotrophs. Further, after repurification, the $R m$ of corresponding isozymes was higher in genotype $M$ than in genotype $R$, indicating that the structural differences between corresponding isozymes of the two genotypes were not destroyed by the isolation procedure. A genotypic difference in the specific activity of isozyme 4 compared with isozymes 1 and 2 was detected, and the tyr-try/ peptide ratios of isozymes 1,2 , and 4 were higher for genotype $M$ than for genotype $R$ (significantly higher in the case of isozyme 4). The peroxidase molecule consists of protein and carbohydrate moieties, and the possibility of other attached components has not been ruled out. It should be noted, therefore, that peroxidase differences between genotypes or between isozymes need not necessarily stem from differences in the protein moiety of the molecule. Even apparent differences in protein content could reflect modifications in non-protein components which alter the reactivity of the molecule in a given assay system. Current research has also shown that the total concentration of the samples applied at each step of the procedure can be increased five to six times over the concentration used here without increasing the column dimensions or altering the elution profiles. With increased concentrations of starting material, sufficient quantities of all four isozymes will be able to be isolated to allow extensive examination of physical and biochemical characteristics and to allow comparisons of these characteristics to be made between isozymes, between genotypes, and between genotrophs.

\section{Acknowledgment}

The work was supported by a grant from the National Research Council of Canada, to whom thanks are extended.

BAdin. J., C. JACKson, and M. Schubert, 1953. Improved method for determination of plasma polysaccharides with tryptophan. Proc. Soc. Exp. Biol. Med. 84: 288-291.

DURRANT, A. 1962a. Induction, reversion and epitrophism of flax genotypes. Nature (London), 196: 1302-1304. 1962 b. The environmental induction of heritable change in Limum. Heredity, 17: 27-61.

1971. Induction and growth of flax genotrophs. Heredity, 27: 277-298.

FIEldes, M. A., and H. TYSON. 1972. Activity and relative mobility of peroxidase isoenzymes in genotrophs and 
genotypes of flax (Linum usitatissimum L.). Can. J. Genet. Cytol. 14: 625-636.

- 1973a. Activity and relative mobility of peroxidase and esterase isozymes of flax (Linum usitatissimum) genotrophs. 1. Developing main stems. Can. J. Genet. Cytol. 15: 731-744.

1973b. Acitivity and relative mobility of peroxidase and esterase isozymes of flax (Linum usitatissimum) genotrophs. II. $F_{1}$ hybrids and nuclear DNA reversion types. Can. J. Genet. Cytol. 15: 745-755.

HART, M. A., H. Tyson, and R. Bloomberg. 1971. Measurement of activity of peroxidase isozymes in flax (Linum usitatissimum). Can. J. Bol. 49: 2129-2137.

Lowry, O. H., N. J. Rosebrough, A. L. Farr, and R. L. RANDALL. 1951. Protein measurements with the Folin phenol reagent. J. Biol. Chem. 193: 265-275.

Maenly, A. C.. and B. Chance. 1954. Methods of biochemical analysis. 1. Interscience Publications, New York. pp. 358-424.
MONTGOMERY, R. 1972. Glycoproteins, their composition, structure and function. Part A. Edited by A. Gottschalk. Elsevier Publishing Co., New York. pp. 518-528.

MoritA, Y.. and C. YoshidA. 1970. Aromatic acid residues in Japanese-radish peroxidase $a$ and apoenzyme. Agric. Biol. Chem. 34: 590-598.

Morita, Y., C. Yoshida, I. Kitamura, and S. IDA. 1970. Isoenzymes of Japanese-radish peroxidase. Agric. Biol. Chem. 34: 1191-1197.

Morita. Y.. C. Yoshida, and Y. Maeda. 1971. Properties and structures of peroxidase isoenzymes of Japanese-radish. Agric. Biol. Chem. 35: 1074-1083.

Shannon, L. M., E. Kay, and J. Y. Lew. 1966. Peroxidase isozymes from horseradish roots. 1. Isolation and physical properties. J. Biol. Chem. 24: 2166-2172.

WADDELL, W. J., and N. C. Hill. 1956. A simple ultraviolet spectrophotometric method for the determination of protein. J. Lab. Clin. Med. 48: 311-314. 